\title{
KORELASI ANTARA PERENCANAAN PEMBELAJARAN DENGAN HASIL BELAJAR DI SMPI BABURROHMAH MOJOSARI MOJOKERTO 2017-2018
}

\author{
Mas'ulil Munawaroh \\ Sekolah Tinggi Agama Islam Sabilul Muttaqin Mojokerto \\ munawaroh1980@gmail.com \\ Abdul Muhaimin \\ Institut Pesantren KH Abdul Chalim Mojokerto \\ abdmuha356@gmail.com
}

\begin{abstract}
In order to realize a quality learning process, it requires professional teachers, especially in planning learning which is teacher preparation before implementing the learning process when the learning process takes place. Planning is determining what will be done. Planning contains a series of broad decisions and explanations of objectives, determination of policies, determination of programs, determination of specific methods and procedures and determination of activities based on daily schedules. This research took place at the Baburrohmah SMPI, Jurangsari Hamlet, Middle Hemisphere Village, Mojosari District, Mojokerto Regency. The type of research in this study is included in quantitative and qualitative research. The technique used to collect data on whether the teacher prepares a learning plan well in the teaching and learning process is a questionnaire (questionnaire) that has previously been tested for validity and reliability according to the standards. Subsequent data analysis was carried out with the help of the SPSS version 22.0 computer program to determine the level of contribution between independent variables and bound and histogram. Based on the results of data analysis regarding the relationship of learning planning with student learning outcomes, it can be concluded that: there is a relationship between learning planning with learning outcomes of class VIII students of SMPI Baburrohmah but very low and not significant. This is evidenced by the value of r-count (0.145) ranging from 0,000 to 0.200, and r-count (0.145) is smaller than r-table (0.254) at a significant level $a=0.05$. The magnitude of the relationship (Coefficient of Determination) between Learning Planning (variable X1), with Learning Outcomes (variable Y) class VIII Baburrohmah SMPI in 2016/2017 amounting to $02.11 \%$, the remaining $91.89 \%$ is influenced by other factors.
\end{abstract}

Keywords: Learning Planning, Learning Outcomes, Islamic School.

Nazhruna: Jurnal Pendidikan Islam

Vol. 2 No 2 2019. Issn: 2614-8013. Hal. 310-327

DOI: https://doi.org/10.31538/nzh.v2i2.338 


\begin{abstract}
Abstrak
Dalam rangka mewujudkan proses pembelajaran yang berkualitas tersebut, membutuhkan guru yang profesional, terlebih dalam merencanakan pembelajaran yang merupakan persiapan guru sebelum melaksanakan proses pembelajaran ketika proses pembelajaran berlangsung. Perencanaan adalah menentukan apa yang akan dilakukan. Perencanaan mengandung rangkaian-rangkaian keputusan yang luas dan penjelasan-penjelasan dari tujuan, penentuan kebijakan, penentuan program, penentuan metode-metode dan prosedur tertentu dan penentuan kegiatan berdasarkan jadwal sehari-hari. Penelitian ini bertempat di SMPI Baburrohmah, Dusun Jurangsari Desa Belahan Tengah, Kecamatan Mojosari Kabupaten Mojokerto. Jenis penelitian dalam penelitian ini termasuk kedalam penelitian kuantitatif dan kualitatif. Teknik yang digunakan untuk mengumpulkan data apakah guru menyusun perencanaan pembelajaran dengan baik dalam proses belajar mengajar adalah kuisioner (angket) yang sebelumnya sudah dilakukan uji validitas dan reliabilitas sesuai standarnya. Analisis data selanjutnya dilakukan dengan bantuan komputer program SPSS versi 22.0 untuk menentukan tingkat kontribusi antara variabel bebas dan terikat dan membuat histogram. Berdasarkan hasil analisis data mengenai hubungan perencanaan pembelajaran dengan hasil belajar siswa, dapat disimpukan bahwa: ada Hubungan antara perencanaan pembelajaran dengan hasil belajar siswa kelas VIII SMPI Baburrohmah namun sangat rendah dan tidak signifikan . Hal ini dibuktikan dengan nilai r-hitung $(0,145)$ berkisar antara $0,000 \mathrm{~s} / \mathrm{d}$ 0,200, dan r-hitung $(0,145)$ lebih kecil dari r-tabel $(0,254)$ pada taraf siginifikan $a=0,05$. Besarnya hubungan (Koefisien Determinasi) antara Perencanaan Pembelajaran (variabel $\mathrm{X}_{1}$ ), dengan Hasil Belajar ( variabel Y) kelas VIII SMPI Baburrohmah tahun 2016/2017 sebesar 02,11\% selebihnya 91,89\% dipengaruhi oleh faktor lain.
\end{abstract}

Kata Kunci: Perencanaan Pembelajaran, Hasil Belajar. Sekolah Islam. 
Nazhruna: Jurnal Pendidikan Islam

\section{Pendahuluan}

Manajemen kurikulum merupakan bagian dari gugusan substansi manajemen pendidikan. Manajemen pendidikan seringkali diartikan pengelolaan mata pelajaran dalam sebuah lembaga. Manajemen ini sebenarnya mencakup banyak hal, di antaranya adalah menetapkan kurikulum yang akan ditetapkan, pengembangan kurikulum baru, pembagian tugas mengajar, penyusunan tugas mengajar (prota/promes), pengaturan jadwal pembelajaran, pengaturan permulaan tahun ajaran, pelaksanaan pembelajaran/realisasi kurikulum, evaluasi pembelajaran, pembelajaran remedial, pengaturan penutup tahun ajaran. ${ }^{1}$ Salah satu aktifitas dari manajemen kurikulum adalah perencanaan pembelajaran. Seorang guru harus mampu merencanakan pembelajaran dengan baik agar proses pembelajaran menjadi bermutu dengan tetap memperhatikan karakteristik peserta didik $^{2}$. Dalam Bab IV pasal 19 ayat (1) SNP ditentukan bahwa proses pembelajaran pada satuan pendidikan diselenggarakan secara interaktif, inspiratif, menyenangkan, menantang, memotivasi peserta didik untuk berpartisipasi aktif, serta memberikan ruang yang cukup bagi prakarsa, kreativitas, dan kemandirian sesuai bakat, minat dan perkembangan fisik dan psikologis peserta didik.

Dalam rangka mewujudkan proses pembelajaran yang berkualitas tersebut, membutuhkan guru yang profesional, terlebih dalam merencanakan pembelajaran yang merupakan persiapan guru sebelum melaksanakan proses pembelajaran dan pengelolaan kelas ketika proses pembelajaran berlangsung. William H. Newman, sebagaimana dikutip oleh Majid mengemukakan bahwa perencanaan adalah menentukan apa yang akan dilakukan. Perencanaan mengandung rangkaian-rangkaian keputusan yang luas dan penjelasan-penjelasan dari tujuan, penentuan kebijakan, penentuan program, penentuan metode-metode dan prosedur tertentu dan penentuan kegiatan berdasarkan jadwal sehari-hari. ${ }^{3}$

${ }^{1}$ Daryanto, Administrasi Pendidikan (Jakarta: Rineka Cipta, 1998), 52. Dilengkapi dengan paparan oleh Hadari Nawawi, Organisasi Sekolah dan Pengelolaan Kelas (Jakarta: Masagung, 1989), 82. Suharsimi Arikunto, Pengelolaan Kelas dan Siswa (Jakarta: Raja Grafindo Persada, 1996).

${ }^{2}$ Ahmad Fauzi, "Kepemimpinan Kepala Madrasah Dalam Mengembangkan Lembaga Pendidikan Islam," Nidhomul Haq: Jurnal Manajemen Pendidikan Islam 2, no. 2 (December 6, 2017): 42-53; Muhammad Anas Maarif, "Optimalisasi Pembelajaran Pendidikan Islam Di Sekolah/Madrasah Upaya Dan Faktor Penghambat Pembelajaran Pendidikan Islam," Falasifa: Jurnal Studi Keislaman 8, no. 2 (2018): 273-290.

3 A. Madjid, Perencanaan Pembelajaran, (Bandung: PT. Remaja Rosda Karya, 2008), 15. 
Adapun usaha yang dilakukan oleh sekolah, khususnya terhadap guru diantaranya; mengadakan pelatihan-pelatihan di sekolah seperti pelatihan membuat perencanaan pembelajaran dan workshop-workshop tentang pembelajaran dalam rangka meningkatkan kualitas pembelajaran. Hal inilah yang menjadi alasan penulis untuk melakukan penelitian di SMPI Babur Rohmah Belahan Tengah Mojosari. Untuk keperluan penelitian maka diajukan rumusan masalah sebagai berikut: Adakah hubungan antara perencanaan pembelajaran dengan hasil belajar siswa SMPI Babur Rohmah? Seberapa besar hubungan antara perencanaan dan pengelolaan kelas dengan hasil belajar siswa SMPI Babur Rohmah, baik secara sendirisendiri atau secara bersama-sama?

\section{Perencanaan Pembelajaran}

Perencanaan dalam bahasa Inggris dikenal dengan istilah plan artinya serangkaian kegiatan yang akan dilakukan dimasa yang akan datang. Lesson plan berati perencanaan pembelajaran. Selain plan juga dikenal istilah design (Indonesiannya desain) yang dapat juga diartikan perencanaan. ${ }^{4}$ Perencanaan yang dalam ilmu manajemen disebut planning, adalah persiapan menyusun suatu keputusan berupa langkah-langkah penyelesaian suatu masalah atau pelaksanaan suatu pekerjaan yang terarah pada pencapaian tujuan tertentu. Secara sederhana perencanaan adalah pemikiran sebelum pelaksanaan tugas. ${ }^{5}$ Hamzah B. Uno mendefinisikan perencanaan sebagai hubungan antara yang ada sekarang (what is) dengan bagaimana seharusnya (what should be) yang bertalian dengan kebutuhan, penentuan tujuan, prioritas program, dan lokasi sumber ${ }^{6}$. Perencanaan juga dapat didefinisikan sebagai suatu cara mengatisipasi dan menyeimbangkan perubahan. Definisi ini menurut Uno, mengasumsikan bahwa perubahan selalu terjadi. Perubahan lingkungan harus selalu diantisipasi sehingga perubahan berimabang dengan perubahan dalam pembelajaran disekolah atau madrasah. ${ }^{7}$

Berangkat dari definisi-definisi tentang perencanaan sebagaimana dikemukakan para pakar pendidikan di atas, dapat disimpulkan bahwa

4 Ali mustofa, Hanun Asrohah, Bahan Ajar Perencanaan Pembelajaran, (Surabaya: Kopertais IV Press, 2011), 6.

${ }^{5}$ Ahmad Rohani, Pengelolaan Kelas, (Jakarta: Rineka Cipta, 2004), 66-67.

${ }^{6}$ Muhammad Anas Ma`arif and Muhammad Husnur Rofiq, "Pola Pengembangan Kurikulum Pendidikan Pesantren Berkarakter: Studi Pondok Pesantren Nurul Ummah Mojokerto," TADRIS: Jurnal Pendidikan Islam 13, no. 1 (September 7, 2018): 1-16, https://doi.org/10.19105/tjpi.v13i1.1635.

${ }^{7}$ Hamzah B. Uno, Perencanaan Pembelajaran, (Jakarta: Bumi Aksara, 2008), 82. 
Nazhruna: Jurnal Pendidikan Islam

setidaknya kata perencanaan memiliki tiga makna. Pertama, perencanaan adalah usaha mencari wujud yang kan datang serta usaha untuk mencapainya. Kedua, perencanaan bermakna usaha menghilangkan kesenjangan antara keadaan masa sekarang dengan masa yang kan datang. Ketiga, perencanaan adalah usaha merubah keadaan agar sejaln dengan keadaan lingkungan yang juga berubah.

Pembelajaran atau pengajaran adalah upaya membelajarkan siswa. Dalam pengertian ini secara implisit dalam pengajaran terdapat kegiatan memilih, menetapkan, mengembangkan metode untuk mencapai hasil pengajaran yang diinginkan. Pemilihan, penetapan dan pengembangan metode ini didasarkan pada kondisi pengajaran yang ada. Kegiatan ini pada dasarnya merupakan kegiatan inti dari perencanaan pembelajaran. ${ }^{8}$

Sedangkan Dimyati dan Mudjiono mendefinisikan pembelajaran sebagai kegiatan guru secara terprogram dalam desain instruksional, untuk membuat siswa belajar secara aktif, yang menekankan pada penyediaan sumber belajar. ${ }^{9}$ Dengan kata lain pembelajaran atau pengajaran adalah suatu cara bagaimana mempersiapkan pengalaman belajar bagi peserta didik. ${ }^{10}$

Berdasarkan dari pengertian perencanaan dan pembelajaran sebagaimana dijelaskan dapat disimpulkan bahwa perencanaan pembelajaran merupakan perencanaan yang sistematik dalam suatu pengajaran yang akan dimanifestasikan bersama-sama peserta didik. Kesimpulan di atas juga sesuai dengan apa yang dikemukakan oleh Madjid yang menyatakan bahwa perencanaan pembelajaran adalah proses penyusunan materi pelajaran, penggunaan media pembelajaran, penggunaan pendekatan dan metode pengajaran, dan penilaian dalam suatu alokasi waktu yang akan dilaksanakan pada masa tertentu untuk mencapai tujuan yang telah ditentukan. Konsep tersebut mengandung dua pemikiran utama, yaitu proses pengambilan keputusan dan pengetahuaan profesional tentang proses pengajaran.

${ }^{8}$ I Nyoman Sudana Degeng, Buku Pegangan Teknologi Pendidikan, Pusat Antar Universitas Untuk Peningkatan dan Pengembangan Aktivitas Instruksional Universitas Terbuka (Jakarta: Depdikbud RI, Dirjen Dikti,1993), h. 1. Bandingkan dengan Sardiman, Interaksi \& Motivasi Belajar Mengajar, (Jakarta PT. Raja Grafindo Persada, 2007), h. 47-48.

${ }^{9}$ Dimyati dan Mudjiono, Belajar dan Mengajar (Jakarta: Rineka Cipta, 2006), h. 297

${ }^{10}$ Mulyani Sumantri, Kurikulum dan Pengajaran (Jakarta: Proyek LPTK, 1998), h. 95 


\section{Dimensi-dimensi Perencanaan Pembelajaran}

Menurut Harjanto dimensi perencanaan pengajaran berkaitan dengan cakupan dan sifat-sifat dari beberapa karakteristik yang ditemukan dalam perencanaan pengajaran. Pertimbangan dimensi-dimensi itu menuntut diadakannya perencanaan komprehensif yang menalar dan efisien, yakni:

1. Signifikansi

Tingkat signifikansi tergantung pada tujuan pendidikan yang diajukan dan signifikansi dapat ditentukan berdasarkan kriteria-kriteria yang dibangun selama proses perencanaan.

2. Feasibilitas

Maksudnya perencanaan harus disusun berdasarkan pertimabangn realistik baik yang berkaitan dengan biaya maupun pengimplementasiaannya.

3. Relevansi

Konsep relevansi berkaitan dengan jaminan bahwa perencanaan memungkinkan penyelesaian persoalan secara lebih spesifik pada waktu yang tepat agar dapat dicapai tujuan spesifik secara optimal.

4. Kepastian

Konsep kepastian minimun diharpkan dapat mengurangi kejadiankejadian yang tidak terduga.

5. Ketelitian

Prinsip utama yang perlu diperhatikan adalah agar perencanaan pengajaran disusun dalam bentuk yang sederhana, serta perlu diperhatikan secara sensitif kaitan-kaitan yang pasti terrjadi antara berbagai komponen.

6. Adaptabilitas

Diakui bahwa perencanaan pengajaran bersifat dinamis, sehingga perlu senantiasa mencari informasi sebagai umpan balik. Penggunaan berbagai proses memungkinkan perencanaan yang fleksibel atau adaptable dapat dirancang untuk menghindari hal-hal yang tidak diharapkan.

7. Waktu

Faktor yang berkaitan dengan waktu cukup banyak, selain keterlibatan perencanaan dalam mempredikisi masa depan, juga validasi dan reliabilitas 
Nazhruna: Jurnal Pendidikan Islam

analisis yang dipakai, serta kapan untuk menilai kebutuhan kependidikan masa kini dalam kaitannya dengan masa mendatang.

8. Monitoring

Monitoring merupakan proses mengembangkan kriteria untuk menjamin bahwa berbagai komponen bekerja secara efektif.

9. Isi Perencanaan

Isi perencanaan merujuk pada hal-hal yang akan direncanakan. ${ }^{11}$

\section{Hasil Belajar dan Faktor-Faktor yang Mempengaruhinya}

Secara terminologi, hasil adalah hasil yang telah dicapai, dilakukan, dikerjakan, dan sebagainya. ${ }^{12}$ Jadi hasil belajar itu mencerminkan kemampuan siswa dalam memenuhi suatu tahapan pencapaian pengalaman belajar dalam suatu kompetensi dasar. ${ }^{13}$ Artinya, hasil belajar itu merupakan kemampuan siswa yang di peroleh melalui belajar. Dan untuk mengetahui hasil belajar tersebut adalah dengan penilaian.

Menurut Glasser sebagaimana dikutip oleh Nasution, penilaian terbagi kepada dua macam, yakni norm-referenced yaitu penilaian yang didasarkan atas penilaian murid dibandingkan dengan hasil seluruh kelas dan criterion-referenced yaitu menilai hasil belajar anak berdasarkan standar dan kriteria tertentu, yakni yang ditentukan oleh tujuan pelajaran. ${ }^{14}$ Dan menurut Syaiful Bahri, indikator yang banyak dipakai sebagai tolak ukur keberhasilan adalah daya serap. ${ }^{15}$

Adapun untuk mengukur atau mengevaluasi hasil belajar harus menjangkau tiga ranah pembelajaran, ranah kognitif, afektif, dan psikomotor bahkan mungkin termasuk kemampuan metakognitif. ${ }^{16}$ Dengan demikian standar tes sangat tergantung pada indikator kompetensi yang

${ }^{11}$ Harjanto, Perencanaan Pengajaran, (Jakarta: Rineka Cipta, 2006, 4-5.

${ }^{12}$ W. S Winkel, Psikologi Pengajaran (Yogyakarta: Media Abadi, 2007), h. 146

13 Abdul Majid dan Dian Andayani, Pendidikan Agama Islam Berbasis Kompetensi, Konsep dan Implementasi Kurikulum 2004 (Bandung: Remaja Rosdakarya, 2004), 92

${ }^{14}$ S. Nasution, Berbagai Pendekatan dalam Proses Belajar \& Mengajar (Jakarta : Bumi Akasara, 2006), 193.

${ }^{15}$ Syaiful Bahri Djamarah dan Aswan Zain, Strategi Belajar Mengajar (Jakarta: Rineka Cipta,

2002), 120. Lihat juga Muhibbin Syah, Psikologi Belajar (Ciputat: Logos Wacana Ilmu, 1999),h. 193

16 Dede Rosyada, Paradigma Pendidikan Demokratis "Sebuah Model Pelibatan Masyarakat dalam Penyelenggaraan Pendidikan” (Jakarta : Kencana, 2004), 191 
hendak dicapai, jadi tidak sangat fair jika kompetensi yang dikehendak dikembangkan itu menuju ranah afektif atau psikomotorik, sementara semua tesnya kognitif. Oleh karena itu semestinya tes yang dikembangkan harus mencakup tiga ranah tersebut.

Jadi dapat disimpulkan bahwa indikator hasil belajar itu bisa dilihat dari kemampuan siswa dalam menguasai indikator kompetensi dari materi pelajaran yang telah di pelajari dengan melalui alat ukur tes. Secara global faktor-faktor yang mempengaruhi belajar siswa dapat dibedakan menjadi dua macam, yakni faktor internal dan faktor eksternal. Faktor internal meliputi 1) Aspek Fisiologis

Aspek Fisiologis berkaitan dengan kondisi jasmani, dimana kondisi jasmani ini sangat berpengaruh pada proses belajar. Bagi kondisi jasmani yang sakit, tidak segar, kelelahan, mengantuk akan membuyarkan konsentrasi belajar bahkan tidak mampu untuk menyerap materi pelajaran yang dipelajari

2) Aspek psikologis

Banyak faktor yang termasuk aspek psikologis yang dapat mempengaruhi kuantitas dan kualitas perolehan pembelajaran siswa. Namun diantara factor-faktor rohaniah siswa yang pada umumnya dipandang lebih esensial itu adalah sebagai berikut: tingkat kecerdasan/ intelegensia siswa, sikap siswa, bakat siswa, minat siswa, dan motivasi siswa. ${ }^{17}$

Faktor lain yang ikut mempengaruhi keberhasilan belajar adalah motivasi siswa. Menurut Oemar Hamalik, motivasi siswa adalah perubahan energi dalam diri (pribadi) seseorang yang ditandai dengan timbulnya perasaan dan reaksi untuk mencapai tujuan. ${ }^{18}$ Sedangkan menurut Gleitmen dan Reber dalam Muhibbin menyatakan bahwa motivasi adalah keadaan internal organism- baik manusia ataupun hewan- yang mendorongnya untuk berbuat sesuatu. ${ }^{19}$

Jadi jelasnya bahwa motivasi dapat dibedakan menjadi dua macam, yaitu: motivasi intrinsik dan motivasi ekstrinsik, yang merupakan

\footnotetext{
${ }^{17}$ Abdul Hadis, Psikologi Dalam Pendidikan (Bandung: Alfabeta, 2006), h. 49-50

${ }^{18}$ Oemar Hamalik, Proses Belajar Mengajar (Jakarta : Bumi Aksara, 2004), 158-159

${ }^{19}$ Muhibbin Syah, Psikologi.., 137
} 
dorongan untuk melakukan tindakan belajar. Dengan adanya motivasi yang kuat untuk belajar maka akan memperoleh hasil belajar yang baik ${ }^{20}$.

Adapun faktor eksternal siswa terdiri dari faktor lingkungan sosial, faktor lingkungan non sosial, ${ }^{21}$ dan faktor kualitas pengajaran. ${ }^{22}$

1) Faktor Lingkungan Sosial

Faktor sosial di sini maksudnya adalah faktor manusia (sesama manusia), baik manusia itu hadir, maupun kehadirannya itu dapat disimpulkan, jadi tidak langsung hadir. ${ }^{23}$

Menurut Muhibbin lingkungan sosial itu ada terbagi kepada: 1) Sosial sekolah, seperti para guru, para staf administrasi serta temanteman sekelas. 2) Lingkungan sosial siswa, seperti masyarakat, tetangga, dan teman-teman sepermainan disekitar perkampungan siswa berada. 3) Lingkungan sosial yang lebih banyak mempengaruhi kegiatan belajar adalah orang tua dan keluarga siswa sendiri. ${ }^{24}$

2) Faktor Lingkungan Non-sosial

Adapun faktor-faktor lingkungan non-sosial mencakup keadaan udara, suhu udara, cuaca, waktu (pagi, siang atau malam), tempat (letaknya, pergedungannya), alat-alat yang dipakai (seperti alat tulis menulis, buku-buku, alat- alat peraga, dan sebagainya). ${ }^{25}$

Khusus mengenai waktu yang disenangi untuk belajar time preference) seperti pagi atau sore hari. Seorang ahli bernama J. Biggers seperti dikutip Muhibbin Syah berpendapat bahwa belajar pada pagi hari lebih efektif dari pada belajar waktu-waktu lain. Namun menurut penelitian beberapa ahli learning style (gaya belajar), hasil belajar itu tidak tergantung

${ }^{20}$ Nurul Indana, "Penerapan Kurikulum Terintegrasi Dalam Mengembangkan Mutu Belajar Siswa (Studi Kasus Di Sma Darul 'Ulum 1 Unggulan Bppt Jombang),” Nidhomul Haq: Jurnal Manajemen Pendidikan Islam 3, no. 2 (October 17, 2018): 121-47, https://doi.org/10.31538/ndh.v3i2.80.

${ }^{21}$ Sumadi Suryabrata, Psikologi Pendidikan (Jakarta : Raja Grafindo Persada, 1998), 233

${ }^{22}$ Caroll berpendapat bahwa hasil belajar siswa dipengaruhi oleh lima faktor, yakni a) bakat pelajar, b) waktu yang tersedia untuk belajar, c) waktu yang diperlukan siswa untuk menjelaskan pelajaran, d) kualitas pengajaran, dan e) kemampuan individu. Empat faktor yang disebut di atas ( $a, b, c$, dan e ) berkenaan dengan kemampuan individu dan faktor (d) adalan faktor diluar individu (lingkungan). Nana Sudjana, Dasar-dasar Proses Belajar Mengajar (Bandung: Sinar Baru Algensindo, 2005), h.40

${ }^{23}$ Sumadi Suryabrata, Psikologi, 234

${ }^{24}$ Muhibbin Syah, Psikologi, 139

${ }^{25}$ Sumadi Suryabrata, Psikologi..., 233, dan juga Muhibbin Syah, Psikologi.., 139 
secara mutlak, tetapi tergantung pada pilihan waktu yang cocok pada kesiapsiagaan siswa. ${ }^{26}$ Oleh karena itu, di antara siswa ada yang siap belajar di pagi hari, ada pula yang siap pada sore hari, bahkan tengah malam. Perbedaan waktu dan kesiapan belajar inilah yang menimbulkan perbedaanstudy time preference antara seorang siswa dengan siswa lainnya. metode yang digunakan sangat menentukan keberhasilan belajar.

3) Faktor Kualitas Pembelajaran

Selanjutnya faktor yang mempengaruhi keberhasilan belajar adalah kualitas pengajaran. Kualitas pengajaran sangat ditentukan oleh kompetensi profesional guru, yang dapat dilihat dari proses pembelajaran. Pendekatan dan metode apa yang dilakukan guru dalam mengajar. Karena pendekatan dan metode yang digunakan sangat menentukan keberhasilan belajar. ${ }^{27}$

Dalam kegiatan belajar mengajar, pendekatan yang guru ambil akan menghasilkan kegiatan anak didik yang bermacam-macam. Guru yang menggunakan pendekatan individual, misalnya berusaha memahami anak didik sebagai makhluk individual dengan segala persamaan dan perbedaannya. Guru yang menggunakan pendekatan kelompok berusaha memahami anak didik sebagai makhluk sosial. Dari kedua pendekatan tersebut lahirlah kegiatan belajar mengajar yang berlainan, dengan tingkat keberhasilan belajar mengajar yang tidak sama pula. Perpaduan dari kedua pendekatan itu malah akan menghasilkan hasil belajar mengajar yang lebih baik.

\section{Metode Peneletian}

Penelitian ini bertempat di SMPI Baburrohmah, Dusun Jurangsari Desa Belahan Tengah, Kecamatan Mojosari Kabupaten Mojokerto. Jenis penelitian dalam penelitian ini termasuk kedalam penelitian kuantitatif dan kualitatif. $^{28}$ Akan tetapi metode kualitatif hanya sebagai penguat metode kuantitatif. Di mana dalam metode kuantitatif peneliti menyebarkan angket kepada sampel yang telah ditentukan, kemudian dianalisi secara statistik. Sedangkan metode kualitatif data dikumpulkan melalui observasi, wawancara,

${ }^{26}$ Muhibbin Syah, Psikologi, h. 154

${ }^{27}$ Muhibbin Syah, Psikologi.., 154

28 Penggabung kedua metode kualitatif dan kuantitatif dikenal juga dengan istilah triangulasi. Triangulasi merupakan teknik pengumpulan data yang bersifat menggabungkan dari berbagai teknik pengumpulan data dan sumber data yang telah ada. Lihat, Julia Brannen, Memadu Metode Penelitian Kualitatif \& Kuantitatif(Yogyakarta: Pustaka Pelajar2002), 19-29 
dan dokumen yang selanjutnya dianalisis untuk menjadi penguat data dan analisis kuantitatif. Sedangkan pendekatan penelitian yang dipakai oleh penulis menggunakan penelitian korelatif $^{29}$, karena penelitian ini bertujuan untuk mengetahui ada tidaknya hubungan antara perencanaan pembelajaran dan pengelolaan kelas dengan hasil belajar siswa kelas VIII SMPI Babur Rohmah tahun 2017/2018.

Teknik yang digunakan untuk mengumpulkan data apakah guru menyusun perencanaan pembelajaran dengan baik dalam proses belajar mengajar adalah kuisioner (angket) yang sebelumnya sudah dilakukan uji validitas dan reliabilitas sesuai standarnya. Instrumen yang digunakan dalam metode ini ada tiga macam: pertama, kuisioner yang berupa pertanyaan/pernyataan dalam model Rating-Scale ${ }^{30}$ dalam bentuk kontinum dengan empat alternatif jawaban/tanggapan masing-masing alternatif diberi skor yang berbeda, yaitu sangat sering (SS) diberi skor 4, sering (S) diberi skor 3, kadangkadang (KK) diberi skor 2, dan tidak pernah (TP) diberi skor 1. Kedua, kuesioner yang berupa pertanyaan SMPI Baburrohmah dengan dua alternatif jawaban yakni "ya" dan "tidak". Jawaban ya diberi skor 1 , dan jawaban tidak diberi skor $0 .^{31}$

Setelah data angket dan hasil belajar siswa yang diambil dari nilai rapot siswa diperoleh, selanjutnya data tersebut dianalisis dengan menggunakan analisis kuantitatif ${ }^{32}$ yang menggunakan teknik korelasi product

${ }^{29}$ Penelitian korelari bertujuan untuk menemukan ada tidaknya hubungan dan apabila ada, berapa eratnya hubungan serta berarti atau tidak hubungan. Ibid, 270.

30 Dalam skala model rating scale, responden tidak akan menjawab salah satu dari jawaban kualitatif yang telah disediakan, tetapi menjawab salah satu jawaban kuantitatif dengan skor yakni 4, 3, 2, 1. Dan untuk mempermudah pemahaman siswa terhadap angket yang akan disebarkan maka peneliti memberi makna terhadap skor tersebut, yakni skor 4 berarti sangat sering, skor 3 berarti sering, skor 2 berarti kadang-kadang, , dan 1 berarti tidak pernah. Baca Sugiyono, Metode Penelitian Pendidikan (Pendekatan Kuantitatif, Kualitatif, dan R\&D) (Bandung: Alfabeta, 2007), 141.

31 Sugiyono, Metode Penelitian Pendidikan, 139.

32 Analisis kuantitatif disebut juga analisis statistis. Prosesnya dapat dibagi menjadi tiga tahap, yang satu sama lain berkaitan erat. Tahap pertama adalah tahap pendahuluan yang disebut tahap pengolahan data. Tahap berikutnya adalah tahap pokok yang disebut tahap pengorganisasian data.Adapun yang terakhir adalah tahap penemuan hasil. Khususnya pada tahap kedua dan ketiga, pengetahuan dan pengukuran yang cermat menurut ilmu statistik sangatlah diperlukan. Kenyataan inilah yang menyebabkan analisa kuantitatif ini disebut juga analisa statistis. Baca Soetandyo Wignjosoebroto, Pengolahan dan Analisa Data, Redaksi Koentjaraningrat, Metode-Metode Penelitian Masyarakat (Jakarta: PT Gramedia, 1981), 328-329 
moment $^{33}$ dan regresi linier Analisis data selanjutnya dilakukan dengan bantuan komputer program SPSS versi 22.0 untuk menentukan tingkat kontribusi antara variabel bebas dan terikat dan membuat histogram.

\section{Hasil Penelitian dan Pembahasan}

Perhitungan untuk memperoleh angka antara hubungan antara perencanaan pembelajaran dengan hasil belajar siswa dengan menggunakan tabel persiapan " $\mathrm{r}$ " product moment. Berdasarkan data di atas ditemukan bahwa koefisien korelasi data nilai r-hitung berkisar antara 0,000 s/d 0,200, ini dapat diinterpretasikan bahwa hubungan antara Perencanaan Pembelajaran dengan Hasil Belajar siswa kelas VIII SMPI Babur Rohmah Mojosari tahun 2017/2018 adalah termasuk korelasi sangat rendah.

Interpretasi lain dapat dilihat setelah variabel bebas $\left(\mathrm{X}_{1}\right)$ dengan variabel terikat $(\mathrm{Y})$ di atas dimasukkan ke dalam dan diolah dengan program SPSS 22.0 kemudian dianalisis dengan rumus korelasi Product Moment Karl Pearson, maka data tersaji sebagai berikut:

Tabel 1.01

Hasil Korelasi antara Variabel Bebas $\left(\mathrm{X}_{1}\right)$ Perencanaan Pembelajaran dengan

Variabel Terikat (Y) Hasil Belajar siswa kelas VIII SMPI Mojosari dengan rumus Product Moment Program SPSS 22.0

\section{Correlations}

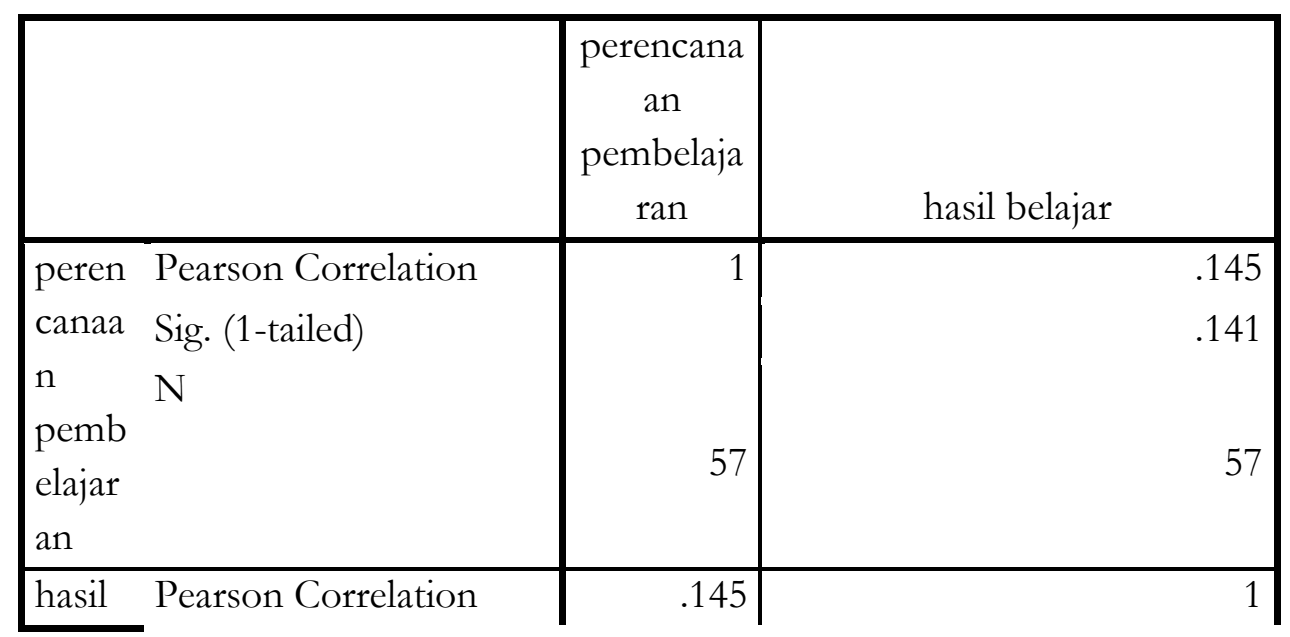

${ }^{33}$ Product momen digunakan untuk menguji hipotesis, yang kemudian dilakukan pengujian persamaan regresi sederhana dari masing-masing variabel penelitian. Lihat Suharsimi Arikunto, prosedur Penelitian (Jakarta: Rineka Cipta, 1996), 123. 
Nazhruna: Jurnal Pendidikan Islam

$\begin{array}{ll}\text { belaja } & \text { Sig. (1-tailed) } \\ \mathrm{r} & \mathrm{N}\end{array}$

Dari tabel correlations ini, koefisien korelasi $\mathrm{r}_{\mathrm{xy}}$ Product Moment di atas dapat diketahui hasil perhitungan $r$-hitung $=0,145$. Jika nilai $r$ hitung dibandingkan dengan nilai $\mathrm{r}$ tabel pada taraf signifikansi $a=0,05$ maka yang akan ditemukan pada tabel harga kritik Product Moment adalah $\mathrm{N}=55$ dengan nilai $r$ tabel 0,266 dan $\mathrm{N}=60$ dengan nilai $r$ tabel 0,254, sementara $\mathrm{N}=57$ tidak ada datanya, maka penulis mengambil data $\mathrm{N}=60$ dengan nilai $\mathrm{r}$ tabel 0,254 dengan alasan 57 lebih dekat untuk dibulatkan menjadi 60, dengan demikian maka didapatkan $r$ hitung $(0,145)<\mathrm{r}$ tabel $(0,254)$. Dari keterangan data tersebut, maka dapat disimpulkan bahwa hubungan antara Perencanaan Pembelajaran dengan Hasil Belajar siswa kelas VIII SMPI Babur Rohmah Mojosari tahun 2017/2018 sangat rendah.

Untuk mengetahui besarnya hubungan (Koefisien Determinasi) antara Perencanaan Pembelajaran (variabel $\mathrm{X}_{1}$ ), dengan Hasil Belajar ( variabel $\mathrm{Y}$ ) diperoleh dengan rumus:

$$
\begin{aligned}
\mathrm{KD} & =\mathrm{r}^{2} \cdot 100 \% \\
& =0,145^{2} \cdot 100 \% \\
& =02,11 \%
\end{aligned}
$$

Keterangan:

$\mathrm{KD}=$ Koefisien Determinasi

$\mathrm{r}^{2}=\mathrm{r}$ hitung product moment

Artinya angka $02,11 \%$ variasi yang terjadi terhadap tinggi rendahnya hasil belajar siswa disebabkan oleh perencanaan pembelajaran dan selebihnya 91,89\% dipengaruhi oleh faktor lain. Dengan demikian proses penghitungan ini sesuai dengan hasil output SPSS 22.0 sebagai berikut:

\section{Tabel 1.02}

Model Summary

Model Summary

\begin{tabular}{|l|r|r|r|c|}
\hline Model & R & R Square & $\begin{array}{r}\text { Adjusted } \\
\text { R Square }\end{array}$ & $\begin{array}{c}\text { Std. Error of the } \\
\text { Estimate }\end{array}$ \\
\hline 1 &, $145^{\mathrm{a}}$ &, 021 &, 003 & 3,41597 \\
\hline
\end{tabular}


Vol. 2 Nomer 22019

a. Predictors: (Constant), Perencanaan Pembelajaran

Keterangan:

$\mathrm{R}=$ Koefisien Korelasi

$\mathrm{R}^{2}=$ Koefisien Determinasi

$\mathrm{R}$ disebut juga dengan koefisien korelasi dapat dibaca bahwa nilai $\mathrm{KK}$ antar variabel perencanaan pembelajaran $\left(\mathrm{X}_{1}\right)$ dengan hasil belajar siswa $(\mathrm{Y})$ adalah 0,145 Hal ini bisa disimpulkan bahwa terdapat hubungan antara kedua variabel tersebut sebesar $14,50 \%$.

R Square disebut dengan koefisien determinasi. Dari tabel dapat dibaca bahwa nilai $\mathrm{R}$ Square $\left(\mathrm{R}^{2}\right)$ adalah 0,021 . Hal ini bisa disimpulkan bahwa $02,10 \%$ variasi yang terjadi terhadap tinggi rendahnya hasil belajar siswa (Y) disebabkan variasi perencanaan pembelajaran $\left(\mathrm{X}_{1}\right)$

Sedangkan untuk uji hipotesis dan regresinya dapat dilihat dari tabel koefisien berikut ini:

Tabel 5.14 Coeffisients (a)

Coefficients $^{\text {a }}$

\begin{tabular}{|c|c|c|c|c|}
\hline \multirow[b]{2}{*}{ Model } & \multicolumn{2}{|c|}{$\begin{array}{c}\text { Unstandardized } \\
\text { Coefficients }\end{array}$} & \multirow{2}{*}{$\begin{array}{c}\begin{array}{c}\text { Standardized } \\
\text { Coefficients }\end{array} \\
\text { Beta }\end{array}$} & \multirow[b]{2}{*}{$\mathrm{T}$} \\
\hline & B & Std. Error & & \\
\hline 1 (Constant) & $\begin{array}{r}68,62 \\
8\end{array}$ & 5,107 & & 13,439 \\
\hline $\begin{array}{l}\text { Perencanaan } \\
\text { Pembelajaran }\end{array}$ & 137 & ,126 & ,145 & 1,087 \\
\hline
\end{tabular}

Coefficientsa

\begin{tabular}{|c|c|}
\hline Model & Sig. \\
\hline $\begin{array}{c}\text { (Constant) } \\
\text { Perencanaan Pembelajaran }\end{array}$ & $\begin{array}{l}, 000 \\
, 282\end{array}$ \\
\hline
\end{tabular}


Nazhruna: Jurnal Pendidikan Islam

a. Dependent Variable: Hasil Belajar

$\mathrm{T}_{\text {hitung }}$ nya didapat sebesar 1,087 $<\mathrm{t}_{\text {tabel }} 2,000$ dengan $\mathrm{df}=60(\mathrm{n}+3)$, dan probabilitas $(p-$ Value $)=0,282>0,05$. jadi $\mathrm{H}_{a}$ ditolak artinya perencanaan pembelajaran $\left(\mathrm{X}_{1}\right)$ itu tidak mempunyai korelasi positif terhadap hasil belajar siswa $(\mathrm{Y})$.

Dan dalam regresinya adalah $\mathrm{Y}=68,628+0,137 \mathrm{X}_{1}$ artinya setiap kenaikan 1 skor perencanaan pembelajaran $\left(\mathrm{X}_{1}\right)$ hanya dapat meningkatkan 0,137 skor hasil belajar siswa $(\mathrm{Y})$.

Jadi dapat disimpulkan bahwa tidak terdapat hubungan positif antara perencanaan pembelajaran dengan hasil belajar siswa. Hal ini tidak berarti bahwa jika perencanaan pembelajaran baik maka hasil belajar siswa juga akan cenderung semakin membaik.

Gambar 1.01 Diagram Histogram Perencanaan Pembelajaran

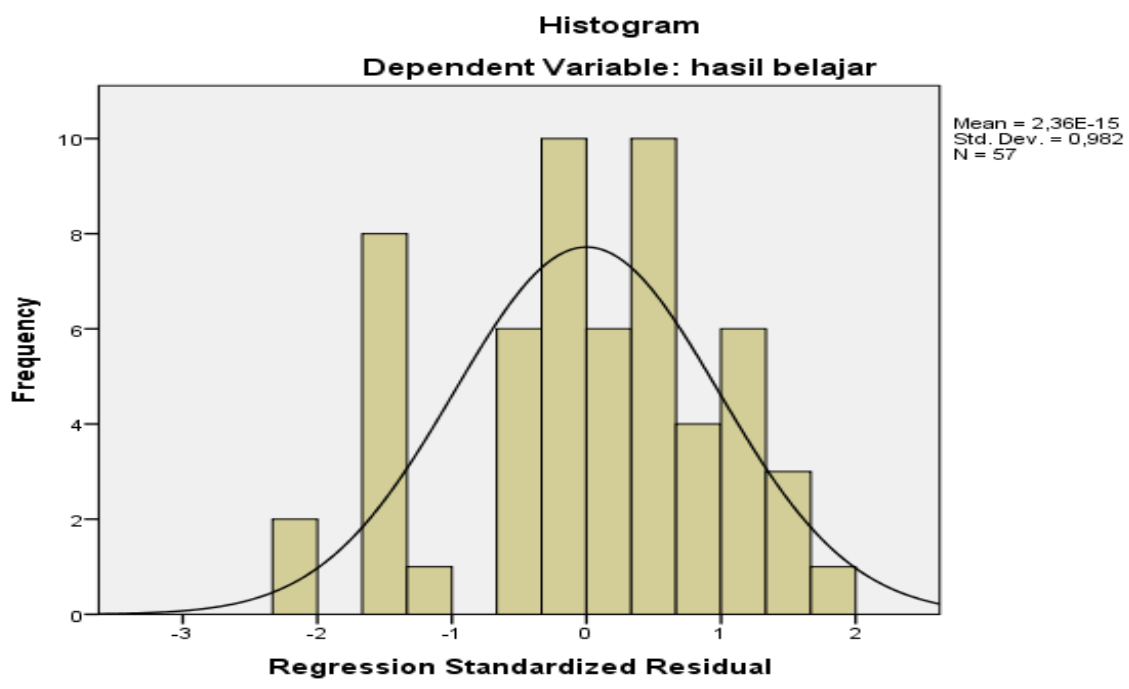

Dari histogram tersebut tampak bahwa kemiringan (skewness) data condong ke arah kiri (kurva juling negatif) ${ }^{34}$ yang berarti bahwa sebagian

Kurva juling negative tersebut menandakan keadaan yang tidak normal. Lebih

Suharsimi Arikunto, Dasar-Dasar Evaluasi, h. 246. Dan Anas Sudijono, Pengantar 
besar (mayoritas) skor data variabel perencanaan pembelajaran berada di bawah rata-rata (mean), yang berarti terdapat ketidaknormalan data guru dalam merencanakan pembelajaran. Ketidaknormalan dimaksud bahwa guru dalam merencanakan pembelajaran ada yang sangat baik, baik, dan ada yang cukup.

\section{Kesimpulan}

Berdasarkan hasil analisis data mengenai hubungan perencanaan pembelajaran dengan hasil belajar siswa, dapat disimpukan bahwa:

1. Ada Hubungan antara perencanaan pembelajaran dengan hasil belajar siswa kelas VIII SMPI Baburrohmah namun sangat rendah dan tidak signifikan . Hal ini dibuktikan dengan nilai r-hitung $(0,145)$ berkisar antara $0,000 \mathrm{~s} / \mathrm{d}$ 0,200 , dan r-hitung $(0,145)$ lebih kecil dari r-tabel $(0,254)$ pada taraf siginifikan $a=0,05$. Artinya tidak terdapat hubungan positif antara perencanaan pembelajaran dengan hasil belajar siswa. Hal ini tidak berarti bahwa jika perencanaan pembelajaran baik maka hasil belajar siswa juga akan cenderung semakin membaik.

2. Besarnya hubungan (Koefisien Determinasi) antara Perencanaan Pembelajaran (variabel $\mathrm{X}_{1}$ ), dengan Hasil Belajar ( variabel Y) kelas VIII SMPI Baburrohmah tahun 2016/2017 sebesar 02,11\% selebihnya 91,89\% dipengaruhi oleh faktor lain. 
Nazhruna: Jurnal Pendidikan Islam

\section{Referensi}

Abdul Majid dan Dian Andayani, Pendidikan Agama Islam Berbasis Kompetensi, Konsep dan Implementasi Kurikulum 2004 (Bandung: Remaja Rosdakarya, 2004.

Arikunto, Suharsimi. Pengelolaan Kelas dan Siswa, Jakarta: Raja Grafindo Persada, 1996.

Asrohah, Hanun, Ali mustofa, Bahan Ajar Perencanaan Pembelajaran,

Surabaya: Kopertais IV Press, 2011.

Brannen, Julia. Memadu Metode Penelitian Kualitatif \& Kuantitatif, Yogyakarta:

Pustaka Pelajar2002.

Daryanto, Administrasi Pendidikan, Jakarta: Rineka Cipta, 1998.

Dede Rosyada, Paradigma Pendidikan Demokratis "Sebuah Model Pelibatan

Masyarakat dalam Penyelenggaraan Pendidikan” Jakarta : Kencana, 2004

Dimyati dan Mudjiono, Belajar dan Mengajar, Jakarta: Rineka Cipta, 2006.

Fauzi, Ahmad. "Kepemimpinan Kepala Madrasah Dalam Mengembangkan

Lembaga Pendidikan Islam." Nidhomul Haq: Jurnal Manajemen Pendidikan Islam 2, no. 2 (December 6, 2017): 42-53.

Hadi , Abdul. Psikologi Dalam Pendidikan, Bandung: Alfabeta, 2006

Hamalik, Oemar. Proses Belajar Mengajar, Jakarta : Bumi Aksara, 2004

Harjanto, Perencanaan Pengajaran, Jakarta: Rineka Cipta, 2006

Indana, Nurul. "Penerapan Kurikulum Terintegrasi Dalam Mengembangkan Mutu Belajar Siswa (Studi Kasus Di Sma Darul 'Ulum 1 Unggulan Bppt Jombang)." Nidhomul Haq: Jurnal Manajemen Pendidikan Islam 3, no. 2 (October 17, 2018): 121-47. https://doi.org/10.31538/ndh.v3i2.80.

Koentjaraningrat, Metode-Metode Penelitian Masyarakat, Jakarta: PT Gramedia, 1981

Madjid, A. Perencanaan Pembelajaran, Bandung: PT. Remaja Rosda Karya, 2008.

Ma`arif, Muhammad Anas, and Muhammad Husnur Rofiq. "Pola Pengembangan Kurikulum Pendidikan Pesantren Berkarakter: Studi Pondok Pesantren Nurul Ummah Mojokerto.” TADRIS: Jurnal Pendidikan Islam 13, no. 1 (September 7, 2018): 1-16. https://doi.org/10.19105/tjpi.v13i1.1635. 
Maarif, Muhammad Anas. "Optimalisasi Pembelajaran Pendidikan Islam Di Sekolah/Madrasah Upaya Dan Faktor Penghambat Pembelajaran Pendidikan Islam." Falasifa: Jurnal Studi Keislaman 8, no. 2 (2018): 273-290.

Muhibbin Syah, Psikologi Belajar, Ciputat : Logos Wacana Ilmu, 1999

Nawawi, Hadari. Organisasi Sekolah dan Pengelolaan Kelas,Jakarta: Masagung, 1989.

Sudjana, Nana. Dasar-dasar Proses Belajar Mengajar, Bandung: Sinar Baru Algensindo, 2005.

Sugiyono, Metode Penelitian Pendidikan (Pendekatan Kuantitatif, Kualitatif, dan R\&D ), Bandung : Alfabeta, 2007.

Soetandyo Wignjosoebroto, Pengolahan S. Nasution, Berbagai Pendekatan dalam Proses Belajar \& Mengajar,Jakarta: Bumi Aksara.

Sumantri, Mulyani. Kurikulum dan Pengajaran, Jakarta: Proyek LPTK, 1998

Suryabrata, Sumadi. Psikologi Pendidikan, Jakarta : Raja Grafindo Persada, 1998.

Syaiful Bahri Djamarah dan Aswan Zain, Strategi Belajar Mengajar, Jakarta: Rineka Cipta, 2002.

Rohani, Ahmad, Pengelolaan Kelas, Jakarta: Rineka Cipta, 2004.

Uno, Hamzah B. Perencanaan Pembelajaran, Jakarta: Bumi Aksara, 2008.

Degeng, I Nyoman Sudana. Buku Pegangan Teknologi Pendidikan, Pusat Antar Universitas Untuk Peningkatan dan Pengembangan Aktivitas Instruksional Universitas Terbuka (Jakarta: Depdikbud RI, Dirjen Dikti,1993), h. 1. Bandingkan dengan Sardiman, Interaksi \& Motivasi Belajar Mengajar, Jakarta PT. Raja Grafindo Persada, 2007.

Winkel,W. S. Psikologi Pengajaran, Yogyakarta: Media Abadi, 2007 